\title{
PANCREATIC INVOLVEMENT IN FATAL HUMAN LEPTOSPIROSIS: CLINICAL AND HISTOPATHOLOGICAL FEATURES
}

\author{
Elizabeth De Francesco DAHER(1,2), Denise Menezes BRUNETTA(1), Geraldo Bezerra da SILVA JÚNIOR(1), Rainardo Antonio PUSTER(1) \&
}

Régia Maria do Socorro Vidal PATROCÍNIO(3)

\begin{abstract}
SUMMARY
Hyperamylasemia has been reported in more than $65 \%$ of patients with severe leptospirosis, and the true diagnosis of acute pancreatitis is complicated by the fact that renal failure can increase serum amylase levels. Based on these data we retrospectively analyzed the clinical and histopathological features of pancreas involvement in 13 cases of fatal human leptospirosis. The most common signs and symptoms presented at admission were fever, chills, vomiting, myalgia, dehydratation, abdominal pain and diarrhea. Trombocytopenia was evident in 11 patients. Mild increased of AST and ALT levels was seen in 9 patients. Hyperamylasemia was recorded in every patient in whom it was measured, with values above $180 \mathrm{IU} / \mathrm{L}$ ( 3 cases). All patients presented acute renal failure and five have been submitted to dialytic treatment. The main cause of death was acute respiratory failure due to pulmonary hemorrhage. Pancreas fragments were collected for histological study and fat necrosis was the criterion used to classify acute pancreatitis. Histological pancreatic findings were edema, mild inflammatory infiltrate of lymphocytes, hemorrhage, congestion, fat necrosis and calcification. All the patients infected with severe form of leptospirosis who develop abdominal pain should raise the suspect of pancreatic involvement.
\end{abstract}

KEYWORDS: Pancreatitis; Leptospirosis; Acute renal failure; Hyperamylasemia.

\section{INTRODUCTION}

Leptospirosis is a disease caused by Leptospira interrogans, of the order Spirochaetalis, and is a worldwide zoonosis ${ }^{20,22,31}$. It can be transmitted by direct contact with urine, blood or tissues of infected animals, or by the exposure to contaminated water ${ }^{20,22,30}$. Therefore, occupational and recreational activities, living conditions and seasonal weather conditions may be associated with a greater risk of infection ${ }^{20,22}$. Severe leptospirosis mortality rate is high ${ }^{10,14}$. In Brazil, the disease is endemic, with outbreaks during the rainy seasons, when flooding occurs $^{22}$.

Leptospirosis is characterized by a broad spectrum of clinical manifestations, which goes from a subclinical infection and self-limited anicteric febrile illness to Weil's disease, a severe and potentially fatal disease characterized by hemorrhage, acute renal failure and jaundice ${ }^{5,12,20,22}$. It can cause diffuse organ involvement due to an extensive vasculitis $^{20,22}$. The serious occurrences of hepatic, renal and vascular dysfunction, and significant central nervous system symptoms have been well documented ${ }^{22,29,30}$. However, the involvement of the pancreas is not yet well studied in human leptospirosis ${ }^{6,16,23,26,28,33,37}$.

The true diagnosis of acute pancreatitis is complicated by the fact that acute renal failure can increase the serum amylase levels ${ }^{15}$.
EDWARDS et al..$^{15}$ reported hyperamylasemia in more than $65 \%$ of 88 patients with leptospirosis and values greater than three times normal were recorded in only $23 \%$ of these patients. The enzymes lipase and elastase-I are known to show the highest specificity for the diagnosis of pancreatitis $s^{27,37}$. It is suggested that a serum amylase level higher than twice the normal value could not be explained only by renal failure ${ }^{21}$. Others have described several cases of leptospirosis and pancreatitis diagnosed by elevated serum amylase and lipase, but without morphologic change detectable by pancreatic ultrasound $\mathrm{d}^{6,16,23,26,28}$.

To obtain new data and to increase the understanding of the involvement of the pancreas in leptospirosis we carried out a retrospective study to evaluate the clinical and histopathological features in cases of fatal human leptospirosis with pancreas involvement.

\section{MATERIAL AND METHODS}

A retrospective study was conducted in 20 patients with fatal leptospirosis admitted between May 1998 and December 2002 to the Walter Cantídio University Hospital, São José Hospital of Infectious Diseases and General Hospital of Fortaleza, northeastern Brazil. All these patients died and were submitted to autopsy at the Department of Pathology of the Federal University of Ceará. Thirteen cases had the pancreas stored for histological analysis. We reviewed the epidemiologic 


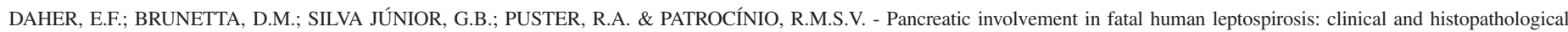
features. Rev. Inst. Med. trop. S. Paulo, 45(6):307-313, 2003.

and clinical data from these patients, except for one who died on hospital admission.

In the present study all the patients had acute renal failure (ARF), defined as serum creatinine $\left(\mathrm{S}_{\mathrm{CR}}\right)$ higher than $1.5 \mathrm{mg} / \mathrm{dL}$, and jaundice on admission. All the patients had epidemiologic history and classical features of clinical leptospirosis. The positive microscopic serum agglutination reactions for leptospirosis, with titers greater than 1:400 were recorded before they died. The anatomo-pathologic findings of muscle and hepatic changes were characteristic of leptospirosis.

The parameters employed to evaluate patients' clinical evolution were: time between the onset of symptoms and hospital admission $(\Delta S)$, time of hospitalization $(\Delta \mathrm{H})$, admission systolic blood pressure (SBP) and diastolic blood pressure (DBP), maximum temperature (T), heart rate (HR) and respiratory rate (RR). Signs and symptoms such as fever, jaundice, dyspnea, myalgia, vomiting, diarrhea, abdominal pain, reduction of urinary output and hemorrhagic manifestations were recorded on admission.

Sera concentrations of urea $\left(\mathrm{S}_{\mathrm{U}}\right)$, creatinine $\left(\mathrm{S}_{\mathrm{CR}}\right)$, potassium $\left(\mathrm{S}_{\mathrm{K}}\right)$, sodium $\left(\mathrm{S}_{\mathrm{Na}}\right)$, ionic calcium $\left(\mathrm{S}_{\text {ionic }{ }^{++}}{ }^{++}\right.$, total bilirubin $(\mathrm{TB})$, aspartate and alanine amino transferase (AST and ALT), serum albumin, blood glucose, arterial blood gases, complete hemogram and peripheral platelet counts were measured on admission and during hospitalization. Data obtained on admission and maximum laboratory values of $\mathrm{S}_{\mathrm{U}}, \mathrm{S}_{\mathrm{CR}}, \mathrm{S}_{\mathrm{K}}$, AST, ALT, TB, WBC count and blood glucose were analyzed during hospital stay, as also were the minimum serum levels of $\mathrm{S}_{\mathrm{K}}, \mathrm{S}_{\mathrm{Na}}$, $\mathrm{S}_{\text {ionic Ca }}{ }^{++}$, albumin, peripheral platelet counts, hematocrit (Hct), hemoglobin $(\mathrm{Hb}), \mathrm{pH}, \mathrm{PaO}_{2}$ and bicarbonate. Serum amylase was requested only in three patients and serum lipase was not available in any patient's medical record, which would be important to diagnose pancreatitis.

Thrombocytopenia was defined as platelet count equal or less than $100,000 / \mathrm{mm}^{3}$ and respiratory failure was defined as $\mathrm{PaO}_{2}$ less than 80 $\mathrm{mmHg}$. Electrocardiogram (ECG) was performed for every patient with cardiac rhythm alteration. Oliguria was defined as a urinary volume less than $600 \mathrm{ml} /$ day, twenty four hours after vigorous fluid replacement.

The medication use, alcohol intake and cause of death were also recorded. Hazardous use of alcohol was defined as binge or chronic heavy drinking, which places asymptomatic drinkers at risk for future health and other problems ${ }^{15}$.

In our hospital there are two groups of infectologists: one does not use penicillin, and the other does. Specific antibiotic therapy consisted of crystalline penicillin in doses of 6 million IU/day intravenously during eight days.

Dialysis was indicated in those patients who remained oliguric even after effective hydration, in those cases where uremia was associated with hemorrhagic phenomena or severe respiratory failure. The type of dialysis indicated was intermittent peritoneal dialysis (IPD) and, in case of extreme hypercatabolism, continuous slow hemodialysis (CSHD).

The pancreas fragments were collected and sections 4-5 $\mu$ m thick of paraffin-embedded tissues were stained with hematoxylin and eosin (H\&E) for standard histology. Fat necrosis was the criterion used to classify pancreatitis. It is the most characteristic signal of acute pancreatitis, according to CRAWFORD \& COTRAN 9 .

The protocol of this study was approved by The Ethical Committee of Walter Cantídio University Hospital, Faculty of Medicine, Federal University of Ceará.

The statistical analysis of the results was done through the program Epi Info 2002. The results were expressed as mean \pm SD.

\section{RESULTS}

Epidemiologic and clinical data from all patients enrolled in the study are summarized in Table 1. Patients' age ranged from 22 to 64 years (mean of $42 \pm 16$ years). Seven patients $(54 \%)$ were male and six were female $(46 \%)$. Four patients referred contact with rats and three with contaminated water flood. From these 13 patients, 10 did not have history of alcohol intake. The drinking was considered hazardous only in two cases.

The $\Delta \mathrm{S}$ ranged from three to 10 days, mean $7 \pm 2$ days and $\Delta \mathrm{H}$ ranged from two to 17 days of hospital admission (mean $4 \pm 4$ days). The SBP on hospital admission ranged from 42 to $130 \mathrm{mmHg}$ (mean 88 $\pm 25 \mathrm{mmHg}$ ), DBP ranged from 26 to $80 \mathrm{mmHg}$ (mean $53 \pm 16 \mathrm{mmHg}$ ) and the mean of $\mathrm{HR}$ on admission was $107 \pm 30 \mathrm{bpm}$ (Table 1 ). The $\mathrm{T}$ on hospital admission ranged from 35 to $39.2^{\circ} \mathrm{C}$ (mean $37.2 \pm 1.4^{\circ} \mathrm{C}$ ) and the mean of maximum $\mathrm{T}$ was $38.2 \pm 1.2^{\circ} \mathrm{C}$. The mean RR on hospital admission was $44 \pm 22 \mathrm{bpm}$.

The most common signs and symptoms were jaundice (92\%), fever $(92 \%)$, vomiting $(83 \%)$, myalgia $(83 \%)$, dyspnea $(83 \%)$, dehydratation (75\%), chills (75\%), abdominal pain $(58 \%)$ and diarrhea $(58 \%)$. Reduction of urinary output (urine volume less than $600 \mathrm{ml} /$ day) was recorded in $9 / 12$ patients $24 \mathrm{~h}$ after hydration. Mechanical ventilation was necessary for seven patients $(53 \%)$ due to respiratory failure.

Penicillin was administered in six patients and other drugs (metronidazole, furosemide, hydrocortisone and ranitidine) in 11 patients. Dialysis was performed in five patients (38\%), being three IPD and two CSHD.

The hemorrhagic manifestation was the main cause of death in eight $(61 \%)$ cases (pulmonary hemorrhage, hemorrhagic cerebrovascular accident and splenic rupture). Only one patient did not present with bleeding. Ten patients presented bleeding in both the respiratory and digestive tracts. The causes of death were acute respiratory failure due to pulmonary hemorrhage in six cases, septic shock in three cases, hemorrhagic cerebrovascular accident in one case and hypovolemic shock, due to a splenic rupture in one case. It was not possible to determine the cause of death in two occasions. One patient died on hospital admission.

The laboratorial data of each case are described in Table 2. The mean maximum levels of $\mathrm{S}_{\mathrm{U}}$ and $\mathrm{S}_{\mathrm{CR}}$ were $185 \pm 86$ and $5.1 \pm 2.9 \mathrm{mg} / \mathrm{dL}$, respectively, in 12 patients. The mean of potassium from admission was $4.2 \pm 0.7 \mathrm{mEq} / \mathrm{L}$. During hospital stay six patients had hyperkalemia (mean $5.7 \pm 0.7 \mathrm{mEq} / \mathrm{L}$ ) and six developed hypokalemia (mean $3.5 \pm$ $0.6 \mathrm{mEq} / \mathrm{L})$. The mean of $\mathrm{S}_{\mathrm{Na}}$ on hospital admission was $130 \pm 2 \mathrm{mEq} / \mathrm{L}$, and 11 patients developed hyponatremia, with minimum $\mathrm{S}_{\mathrm{Na}}$ ranging from 


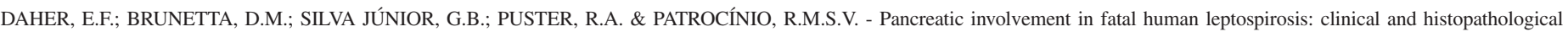
features. Rev. Inst. Med. trop. S. Paulo, 45(6):307-313, 2003.

Table 1

Epidemiologic and clinical parameters in 13 cases of fatal human leptospirosis

\begin{tabular}{|c|c|c|c|c|c|c|c|c|c|c|c|c|c|}
\hline Case number & 1 & 2 & 3 & 4 & 5 & 6 & 7 & 8 & 9 & 10 & 11 & 12 & 13 \\
\hline Age (years) & 64 & 61 & 23 & 53 & 43 & 24 & 29 & 52 & 32 & 29 & 22 & 64 & 55 \\
\hline Sex & $\mathrm{F}$ & $\mathrm{F}$ & $\mathrm{M}$ & $\mathrm{M}$ & M & $\mathrm{M}$ & $\mathrm{F}$ & M & M & $\mathrm{F}$ & $\mathrm{F}$ & $\mathrm{F}$ & $\mathrm{M}$ \\
\hline Profession & RT & HW & $\mathrm{SC}$ & IS & SM & $\mathrm{CW}$ & HW & IS & $\mathrm{BM}$ & HW & - & HW & RT \\
\hline Alcohol intake & $\mathrm{N}$ & $\mathrm{N}$ & $\mathrm{N}$ & $\mathrm{N}$ & $\mathrm{N}$ & $\mathrm{H}$ & $\mathrm{N}$ & $\mathrm{H}$ & $\mathrm{O}$ & $\mathrm{N}$ & - & $\mathrm{N}$ & $\mathrm{N}$ \\
\hline$\Delta \mathrm{S}$ (days) & 3 & 6 & 10 & 6 & 8 & 6 & 7 & 5 & 8 & - & - & 4 & 8 \\
\hline$\Delta \mathrm{H}$ (days) & 3 & 2 & 2 & 2 & 2 & 2 & 2 & 17 & 2 & 2 & - & 3 & 5 \\
\hline $\mathrm{SBP}(\mathrm{mmHg})$ & 70 & 80 & 100 & 80 & 130 & 100 & 80 & 110 & 120 & 80 & - & 42 & 60 \\
\hline $\mathrm{DBP}(\mathrm{mmHg})$ & 40 & 60 & 70 & 60 & 70 & 70 & 60 & 80 & 60 & 40 & - & 26 & 40 \\
\hline HR (bpm) & 96 & 120 & 126 & 72 & 120 & 84 & 100 & 120 & 132 & 124 & - & 86 & 135 \\
\hline Penicillin & $\mathrm{N}$ & $\mathrm{N}$ & $\mathrm{Y}$ & $\mathrm{Y}$ & $\mathrm{Y}$ & $\mathrm{Y}$ & $\mathrm{N}$ & $\mathrm{N}$ & $\mathrm{N}$ & $\mathrm{Y}$ & - & $\mathrm{Y}$ & $\mathrm{N}$ \\
\hline Other drugs & $\mathrm{F}$ & $\mathrm{F}, \mathrm{R}$ & $\mathrm{F}$ & $\mathrm{F}$ & $\mathrm{F}, \mathrm{R}$ & $\mathrm{F}, \mathrm{R}$ & $\mathrm{F}, \mathrm{R}, \mathrm{M}$ & $\mathrm{F}$ & $\mathrm{N}$ & $\mathrm{F}$ & - & $\mathrm{H}, \mathrm{R}$ & $\mathrm{N}$ \\
\hline Oliguria & $\mathrm{N}$ & $\mathrm{Y}$ & $\mathrm{Y}$ & $\mathrm{Y}$ & $\mathrm{Y}$ & $\mathrm{N}$ & $\mathrm{Y}$ & $\mathrm{N}$ & $\mathrm{Y}$ & $\mathrm{Y}$ & - & $\mathrm{Y}$ & $\mathrm{Y}$ \\
\hline Dialysis & IPD & CSHD & $\mathrm{N}$ & IPD & CSHD & $\mathrm{N}$ & $\mathrm{N}$ & IPD & $\mathrm{N}$ & $\mathrm{N}$ & - & $\mathrm{N}$ & $\mathrm{N}$ \\
\hline Cause of death & $\mathrm{RF}$ & RF & SS & ND & SS & $\mathrm{RF}$ & SS & $\mathrm{HCA}$ & HS & $\mathrm{RF}$ & ND & $\mathrm{RF}$ & $\mathrm{RF}$ \\
\hline
\end{tabular}

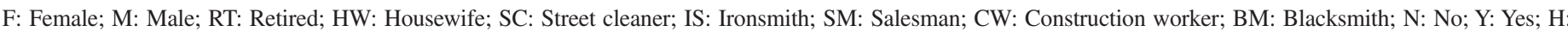

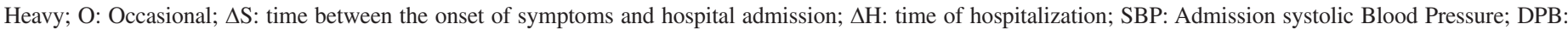

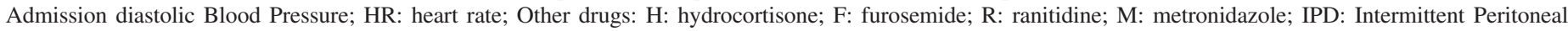

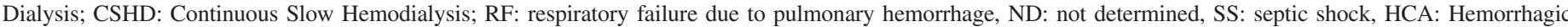
cerebrovascular accident, HS: Hypovolemic shock due to splenic rupture.

Table 2

Main laboratory parameters in 13 cases of fatal human leptospirosis during hospitalization

\begin{tabular}{|c|c|c|c|c|c|c|c|c|c|c|c|c|c|c|}
\hline Case Number & 1 & 2 & 3 & 4 & 5 & 6 & 7 & 8 & 9 & 10 & 11 & 12 & 13 & Reference Value \\
\hline $\mathrm{S}_{\mathrm{K} \mathrm{adm}}(\mathrm{mEq} / \mathrm{dL})$ & 4.0 & 4.5 & 4.9 & 3.3 & 3.6 & 6 & 3.9 & 4.2 & 3.4 & 5.2 & - & 3.7 & 4.0 & $3.5-5.0$ \\
\hline $\mathrm{S}_{\mathrm{CR} \max }^{\mathrm{Kadm}}(\mathrm{mEq} / \mathrm{dL})$ & 6.2 & 6.7 & 7.0 & 5.0 & 9.0 & 3.1 & 5.1 & 8.6 & 1.6 & 2.9 & - & 6.4 & 6.3 & $0.5-1.3$ \\
\hline $\mathrm{S}_{\mathrm{U} \max }(\mathrm{mg} / \mathrm{dL})$ & 201 & 230 & 277 & 144 & 340 & 142 & 169 & 309 & 37 & 50 & - & 193 & 211 & $15-40$ \\
\hline $\mathrm{S}_{\text {Ionic Ca++ min }}(\mathrm{mmol} / \mathrm{L})$ & - & - & - & 1.03 & 0.71 & 1.00 & - & 1.19 & 1.07 & 1.00 & - & 1.13 & 1.18 & $1.1-1.4$ \\
\hline Blood Gluc $_{\text {adm }}(\mathrm{mg} / \mathrm{dL})$ & 241 & 190 & 94 & 82 & 101 & 87 & 270 & 116 & 99 & 355 & - & 185 & 170 & $70-110$ \\
\hline $\mathrm{TB}_{\max }(\mathrm{mg} / \mathrm{dL})$ & 9.07 & - & 2.7 & - & 18 & 9.8 & 4.7 & 19.7 & 12.1 & - & - & 10.4 & 33.9 & $0.3-1.2$ \\
\hline $\mathrm{AST}_{\max }(\mathrm{IU} / \mathrm{L})$ & 154 & - & 61 & - & 65 & 574 & 520 & 88 & 71 & - & - & 167 & 49 & $4-36$ \\
\hline $\mathrm{ALT}_{\text {max }}$ (IU/L) & 42 & - & 55 & - & 52 & 243 & 162 & 38 & 39 & - & - & 185 & 47 & $4-32$ \\
\hline Amylase (IU/L) & 525 & - & - & - & - & - & - & - & - & - & - & 198 & 1450 & $60-180$ \\
\hline Albumin $_{\text {min }}(\mathrm{d} / \mathrm{dL})$ & 2.0 & - & - & - & - & - & 1.9 & 1.7 & 1.7 & - & - & - & 2.3 & $3.5-5.5$ \\
\hline Hematocrit $_{\text {min }}(\%)$ & 25 & 33 & 35 & 32 & 29 & 25 & 34 & 22 & 17.4 & 38.5 & - & 23.6 & 25.9 & $36-54$ \\
\hline Hemoglobin $_{\text {min }}(\mathrm{g} / \mathrm{dL})$ & 8.1 & 10.5 & 11.3 & 10.4 & 9.9 & 8.8 & 11.2 & 7.9 & 5.8 & 12.5 & - & 7.7 & 9.3 & $11.5-18$ \\
\hline $\mathrm{WBC}_{\max }\left(\mathrm{x} 10^{3} \mathrm{~mm}^{3}\right)$ & 7.16 & 10.9 & 13.5 & 15.3 & 7.4 & 14.5 & 16.6 & 27.1 & 38.4 & 12.6 & - & - & - & $3.6-10$ \\
\hline Plat. $_{\min }\left(\mathrm{X} 10^{3} / \mathrm{mm}^{3}\right)$ & 17 & 31 & 46 & 10 & 25 & 28 & 22 & 28 & 100 & 232 & - & 29 & 15 & $150-450$ \\
\hline $\mathrm{Bic}_{\min }(\mathrm{mEq} / \mathrm{L})$ & 21 & 16.1 & 12.0 & 8.5 & 15.7 & 17 & 8.1 & 25.6 & 28.7 & 16 & - & 11.9 & 16 & $22-28$ \\
\hline $\mathrm{PaO}_{2 \text { min }}(\mathrm{mmHg})$ & 45 & 72.7 & 76.6 & 94.7 & 69.8 & 32.3 & 84.3 & 76.6 & 65.6 & 80 & - & 38.4 & 64 & $90-100$ \\
\hline $\mathrm{ECG}$ alt $_{\text {adm }}$ & $\mathrm{AF}$ & $\mathrm{AF}$ & AVB & - & Brad & Brad & - & - & - & Brad & - & - & $\mathrm{AF}$ & - \\
\hline
\end{tabular}

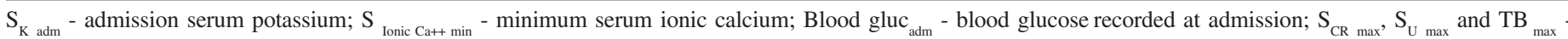

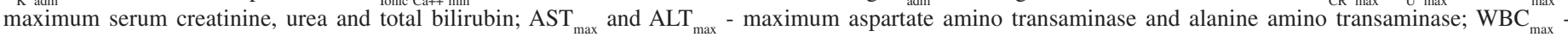

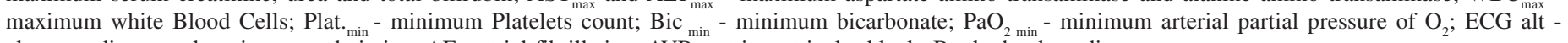
electrocardiogram alterations on admission; AF - atrial fibrillation; AVB - atrioventricular block; Brad - bradycardia.

121 to $140 \mathrm{mEq} / \mathrm{dL}$ (mean $128 \pm 4 \mathrm{mEq} / \mathrm{L}$ ). The serum ionic calcium was recorded in eight patients and hypocalcemia was evident in five cases, ranging from $0.71-1.07 \mathrm{mmol} / \mathrm{L}$ (mean $0.98 \pm 0.13 \mathrm{mmol} / \mathrm{L}$ ). Hyperglicemia (mean $216 \pm 129 \mathrm{mg} / \mathrm{dL}$ ) was seen in $7 / 12$ patients at hospital admission. The serum total bilirubin was recorded in nine patients and the mean maximum levels were $13 \pm 10 \mathrm{mg} / \mathrm{dL}$. The mean maximum levels of hepatic enzymes were $94 \pm 204$ and $96 \pm 79 \mathrm{IU} / \mathrm{L}$ for AST and ALT, respectively. 


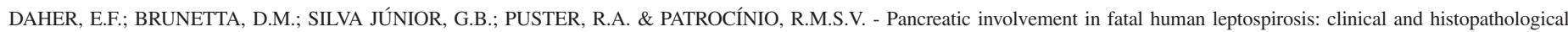
features. Rev. Inst. Med. trop. S. Paulo, 45(6):307-313, 2003.

Trombocytopenia was evident in $11 / 12$ patients with minimum platelet counts ranging from 10 to $232 \times 10^{3} / \mathrm{mm}^{3}$ (mean of $49 \pm 63 \mathrm{x}$ $10^{3} / \mathrm{mm}^{3}$ ). Anemia was seen in $91 \%$ of these patients (mean minimum $\mathrm{Htc}$ of $28.3 \pm 6.2 \%$ and $\mathrm{Hb}$ of $9.5 \pm 1.8 \mathrm{~g} / \mathrm{dL})$, and leucocytosis $(21 \pm 15$ x $10^{3} / \mathrm{mm}^{3}$ ) was present in $7 / 10$ patients. All patients whereas albumin was measured (five cases) showed hypoalbuminemia $(1.98 \pm 0.27 \mathrm{~g} / \mathrm{dL})$. There were also found high levels of amylase in cases 1, 12 and 13 (Table 2). Metabolic acidosis was recorded in nine patients and minimum bicarbonate levels ranged from 8 to $24 \mathrm{mEq} / \mathrm{L}$ (mean of $14 \pm 5.3 \mathrm{mEq} /$ L). During hospitalization, arterial $\mathrm{PaO}_{2}$ was lower than $80 \mathrm{mmHg}$ in $10 / 12$ cases $(57 \pm 17 \mathrm{mmHg})$.

Electrocardiograms were done in seven cases, three had atrial fibrillation, three had bradycardia and atrioventricular block was recorded in one case.
Pancreatic involvement could be noted by laboratory findings (which demonstrated high levels of serum amylase, in three cases in whom it has been measured) and through histological features.

In the present study all the cases had histological pancreatic alterations that ranged from a mild inflammatory infiltrate to moderate fat necrosis with hemorrhagic findings (Table 3). By light microscopy the pancreatic lesions were identified as pancreatic edema in nine cases, mild inflammatory infiltrate of lymphocytes in eight and hemorrhage in five cases. Congestion suggesting pancreatitis was detected in four occasions and fat necrosis was evident in four cases. It was also found calcification in one case. The main histological findings are shown in Fig. 1.

Table 3

Pathologic pancreatic findings by light microscopy in 13 cases of fatal human leptospirosis

\begin{tabular}{|c|c|c|c|c|c|c|c|c|c|c|c|c|c|}
\hline Case number & 1 & 2 & 3 & 4 & 5 & 6 & 7 & 8 & 9 & 10 & 11 & 12 & 13 \\
\hline Fat necrosis & - & - & - & - & - & - & + & - & - & + & ++ & + & - \\
\hline Edema & - & - & + & - & + & + & + & + & ++ & - & ++ & + & + \\
\hline Hemorrhage & - & - & - & - & + & - & - & - & + & ++ & ++ & + & - \\
\hline Congestion & - & - & + & - & - & ++ & - & + & + & - & - & - & - \\
\hline Inflammatory Lymphocytes Infiltrate & + & + & - & + & + & + & + & - & - & + & - & - & + \\
\hline Calcification & - & - & - & - & - & - & - & - & - & + & - & - & - \\
\hline
\end{tabular}

Absent - ; mild + ; modereate ++ ; intense +++
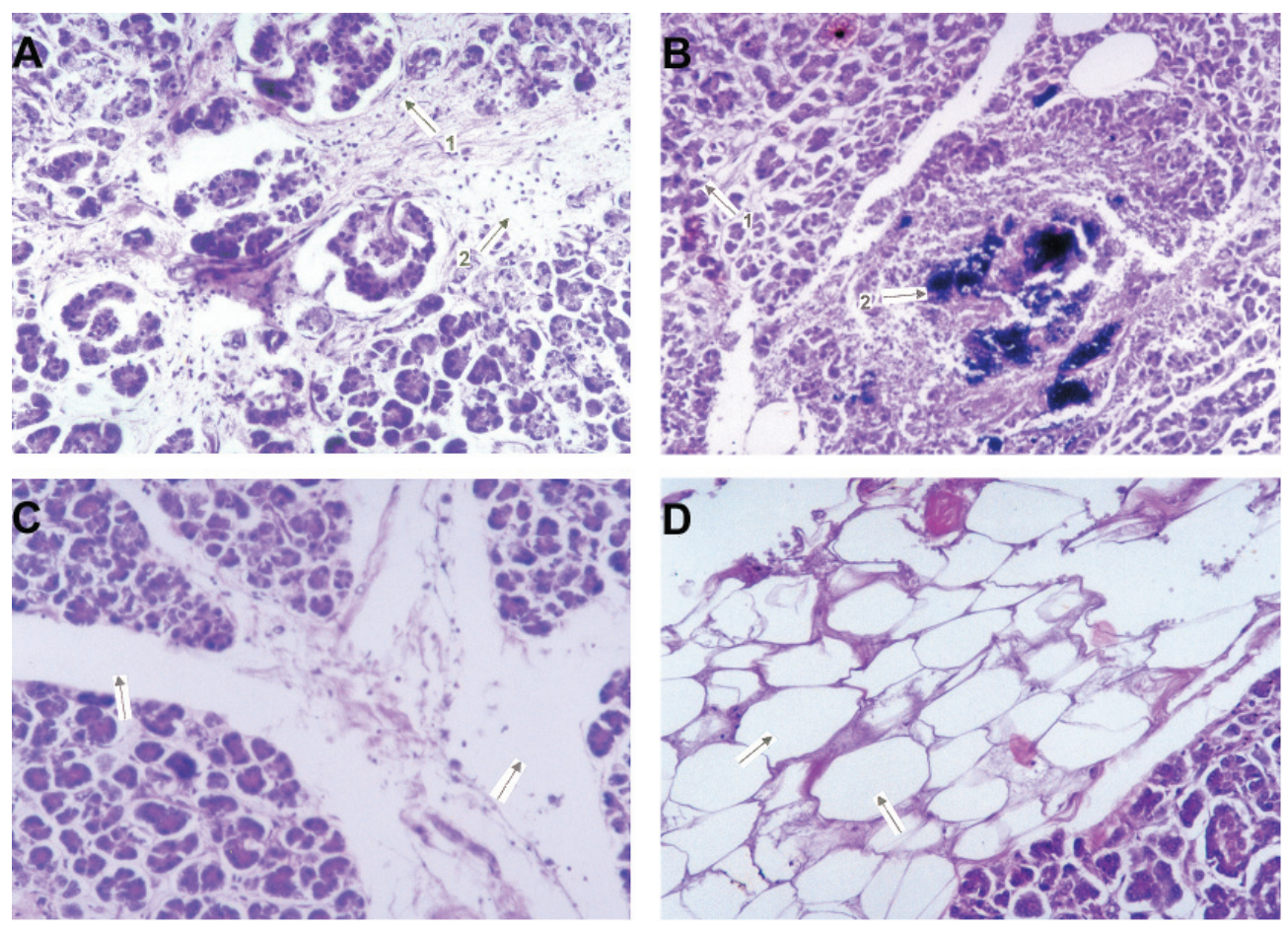

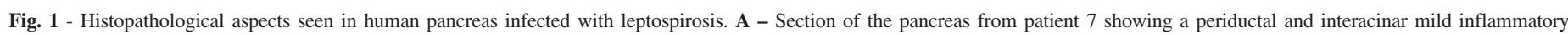

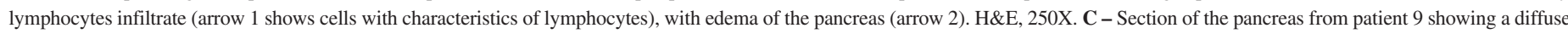

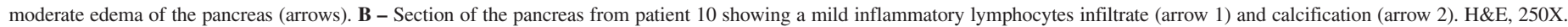
D - Section of the pancreas from patient 11 showing a moderate fat necrosis. H\&E, 250X. 


\section{DISCUSSION}

Leptospirosis is usually an illness of young male people ${ }^{10,22,30}$, but the mean age in the present study showed an older susceptible population. This can be explained by the criterion used to select the sample (patients who died during hospitalization). It is common to find co-morbidities in the elderly population. Almost half of the patients were female, which was also divergent from the literature data ${ }^{20,22,30}$.

In tropical areas there is a poor sewer system and occupation does not represent the most significant risk factor. In Brazil, the increase in demography in the last century caused the creation of slums, where the lack of basic sanitation favors rodent-borne transmission of leptospirosis ${ }^{18}$. The history of contact with rodents and contaminated water was present in more than half of the patients.

In alcohol induced pancreatitis symptoms usually begin 6-12 hours after an episode of binge drinking ${ }^{4}$. In our study, two patients had a past history of hazardous alcohol intake (cases 6 and 8), but they had not drunk any kind of alcoholic substance days before the onset of symptoms.

The most common signs and symptoms presented by the patients were fever, jaundice, vomiting, myalgia, dehydratation, dyspnea, chills, reduction of urinary output and abdominal pain. The mean blood pressure on hospital admission was compatible with arterial hypotension, probably due to dehydration.

The treatment consisted mainly in fluid and electrolytes replacement, diuretics and anti-secretory drugs, depending on each case. The efficacy to the late use of penicillin in the treatment of severe human leptospirosis remain controversial $^{11,38}$. The use of penicillin does not seem to change the outcome of the patients ${ }^{11}$, and this was observed in the cases presented here.

All the patients developed ARF in the present study. The majority of them presented oliguria after fluid replacement. Dialysis was indicated in eight patients, but was performed in only five cases because the others three cases died before dialysis treatment. Leptospirosis is a common cause of ARF, which occurs in 16 to $40 \%$ of cases $^{20}$. A distinction may be done between patients with pre-renal azotemia and those with ARF. Patients with pre-renal azotemia may respond to hydration, and decisions regarding dialysis can be delayed for up to $72 \mathrm{~h}$. In patients with ARF leptospirosis, oliguria is a significant predictor of death ${ }^{10,14}$.

Jaundice with very high levels of serum bilirubin and a mild elevation of AST and ALT were recorded. The jaundice that occurs in leptospirosis is not associated with hepatocellular necrosis and the liver enzymes returns to normal after the illness recovery. Serum bilirubin levels may require several weeks for normalization ${ }^{20}$.

All the patients whose albumin levels were recorded presented hypoalbuminemia, which is an important predictor for a poor survival prognosis. Serum albumin $<3 \mathrm{~g} / \mathrm{dL}$ occurs in $10 \%$ of patients with acute pancreatitis, and this have a strong correlation with severe pancreatitis, leading to a higher risk of death, according to Ranson scores ${ }^{8,17}$.

A high blood glucose level on hospital admission was observed in six cases. Hyperglicemia have already been described in one patient with dengue hemorrhagic fever and pancreatitis ${ }^{17}$.
In the present study the electrolytes abnormalities were also observed. Hypokalemia is a common finding in leptospirosis with ARF. Hypokalemia and polyuria in patients with leptospirosis suggest an increase in distal potassium secretion secondary to increased distal sodium delivery ${ }^{32}$. Ionic hypocalcemia was also observed and could be

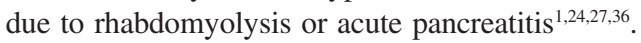

Trombocytopenia, leucocytosis and anemia were evident in almost every patient. Thrombocytopenia in leptospirosis occurs around 50 to $93 \%$ of cases and is transient and does not result from disseminated intravascular coagulation ${ }^{12,20,22}$. In the current study, the majority of patients had an important decrease in platelet count.

The hemorrhagic manifestation was the main cause of death in more than half of the patients. Bleeding is a common complication in leptospirosis and has become the main cause of death in this disease ${ }^{12}$. Hemorrhage occurred mainly in the respiratory tract. Intra-alveolar hemorrhage could be detected in the majority of patients with leptospirosis, even in the absence of overt pulmonary symptoms. Hemorrhagic cerebrovascular accident is a rare complication ${ }^{20}$. Hypovolemic shock due to splenic rupture is a very rare complication, which has been described, by now, in only one case report ${ }^{2}$. Septic shock seen here, established as the cause of death in three cases, could represent a manifestation of pancreatitis. It is known that patients with severe acute pancreatitis without documented sepsis can develop the cardiovascular features of sepsis syndrome ${ }^{40}$.

Metabolic acidosis was evident in nine cases on hospital admission. More than half of the patients were oliguric and $38 \%$ required dialysis treatment. Respiratory insufficiency requiring mechanical ventilation was another complication observed in more than $50 \%$ of the cases.

In seven cases where electrocardiograms were done all the patients presented with cardiac arrhythmias, such as atrioventricular block, tachycardia, bradycardia and atrial fibrillation. The cardiac involvement is common in any form of leptospirosis, but this can be underestimated several times ${ }^{20,22}$. LOMAR et al..$^{22}$ reported $33 \%$ of patients with ECG abnormalities. Arrhythmias were considered a poor prognostic indicator in severe leptospirosis $\operatorname{cases}^{20}$. Pathological findings of cardiac involvement include interstitial myocarditis with lymphocytes and plasma cells infiltration, mononuclear infiltration and petechial hemorrhages in the epicardium, pericardial effusions and coronary arteritis ${ }^{20}$.

Pancreatitis is described as an uncommon complication of leptospirosis, but there are a considerable number of cases documented in literature $6,15,16,23,26,28,37$. The patients presented epigastric pain and jaundice as the main manifestations of pancreatic involvement. The laboratorial diagnosis could be achieved by high sera levels of amylase and lipase, which are more specific for pancreatitis s,26,37. $^{6}$.

The proportion of cases of pancreatitis caused by drugs is estimated to be around $2 \%$ in the general population ${ }^{39}$. Clear evidence of association with pancreatitis exists for some drugs as furosemide and metronidazole, supported by animal experiments or data on the incidence of acute pancreatitis in drug trials ${ }^{35}$. Corticosteroids and ranitidine are also implicated to cause acute pancreatitis ${ }^{4,19}$. In the present study these medications have been administered to some of the patients described here. 


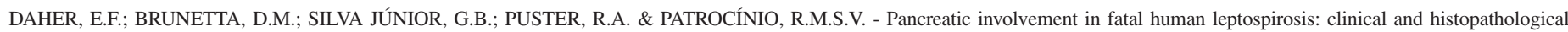
features. Rev. Inst. Med. trop. S. Paulo, 45(6):307-313, 2003.

The serum amylase level is often significantly increased in acute pancreatitis associated with ARF. Clinical symptoms of pancreatitis are not common findings and ultrasound pancreatic morphology does not help in the diagnosis either ${ }^{7,25}$. CHASE et al. ${ }^{7}$ reported that significant elevations (more than 3 times upper limit of normal) in amylase levels were positively associated with a correct diagnosis of acute pancreatitis. EDWARDS et al. ${ }^{15}$ published a 39-month clinical study of 88 patients with leptospirosis and detected hyperamylasemia values greater than three times normal in only $23 \%$ of these patients. Only two patients from his study had abdominal pain and ultrasound examination suggestive of pancreatitis. In the present study, amylase was dosed in only three patients. All of them presented high levels of this enzyme, but in only two it was greater than three times the normal value. The histological finding of fat necrosis was not seen in these patients. MONNO \& MIZUSHIMA ${ }^{26}$ reported a case of leptospirosis associated to pancreatitis and cholecystitis. In this case the serum amylase was 344 IU/L (normal $\leq 83 \mathrm{IU} / \mathrm{L}$ ), lipase $1400 \mathrm{IU} / \mathrm{L}$ (normal $\leq 40 \mathrm{IU} / \mathrm{L}$ ), trypsin $9720 \mathrm{ng} / \mathrm{dL}$ (normal $\leq 550 \mathrm{ng} / \mathrm{dL}$ ), pancreatic secretory trypsin inhibitor $813 \mathrm{ng} / \mathrm{dL}$ (normal $\leq 23 \mathrm{ng} / \mathrm{dL}$ ) and elastase-I $3860 \mathrm{ng} / \mathrm{dL}$ (normal $\leq$ $400 \mathrm{ng} / \mathrm{dL}$ ). Beside the elevated pancreatic enzyme levels, the abdominal ultrasound found normal pancreas. O'BRIEN et al. ${ }^{28}$, published ten cases of leptospirosis and pancreatitis, diagnosed by elevated serum amylase (> $100 \mathrm{IU} / \mathrm{L}$ ), and lipase (> $300 \mathrm{IU} / \mathrm{L})$, but without any detectable ultrasound pancreatic morphologic change. CASELLA \& SCATENA $^{6}$ described a similar case of mild acute pancreatitis and leptospirosis with 1116 IU/L of serum amylase and 802 IU/L of lipase, but also without any ultrasound pancreatic alterations.

The histopathological pancreatic alterations have been reported in severe form of human leptospirosis. $\mathrm{AREAN}^{3}$, based on 33 fatal cases of human leptospirosis, described no gross alteration of the pancreas in any of the cases. Microscopically, severe changes were noted in 12 cases. These consisted of interstitial infiltration by neutrophils and lymphocytes associated with foci of necrosis. In most cases he observed dilated ducts filled with hyaline material admixed with desquamated duct cells. Interstitial edema and focal hemorrhage were also observed. STOLZE et al..$^{33}$, reported a fatal case of Weil's disease with an autopsy that showed primary necrosis of the fat around the gland in the mesentery and under the parietal peritoneum. The pancreas showed slight fibrosis, congestion and calcification by microscopy. However, the pancreatic injury in this case was caused probably by an abdominal trauma accident that the patient had suffered some years previously and the old changes seen in his pancreas (calcification and fibrosis) had no connection with leptospirosis. EDWARDS \& EVARARD ${ }^{16}$ also described a case of acute necrotic pancreatitis associated with leptospirosis, documented by pathology. In the present study, it could be noted, through histological analysis, some alterations such as pancreatic edema, inflammatory lymphocytes infiltrate, hemorrhage features, congestion, fat necrosis and calcification. The patients who had serum amylase recorded showed different histological pancreatic findings. The case 1 (serum amylase of $525 \mathrm{IU} / \mathrm{L}$ ) had only a mild inflammatory infiltrate, the case 12 (serum amylase of 198 IU/L) had fat necrosis, edema and hemorrhagic features, and the case 13 (serum amylase of $1450 \mathrm{IU} / \mathrm{L}$ ) had edema and inflammatory infiltrate. These findings demonstrated that pancreatic changes are not well correlated with high level of serum amylase. In case 10 it was found a mild calcification in the pancreas. There was no evidence of past abdominal trauma in the medical record of this patient. These calcifications could be attributed only to the necrotizing process of acute pancreatitis. According to CRAWFORD \& COTRAN $^{9}$, casts of calcium can be seen inside the necrotic focus of the pancreas in cases of severe acute pancreatitis.

In conclusion, the pancreatic morphology changes were observed in those cases characterized mainly by a diffuse inflammatory process that could be caused by leptospirosis itself. Medication-induced pancreatitis should also be taken under consideration, because some patients received drugs with potential toxic effects to the pancreas, such as furosemide, metronidazole and corticosteroids. Patients with severe form of leptospirosis who develop abdominal pain should raise the suspect of pancreatic involvement. It is also important to determine the levels of serum amylase and lipase in every patient with leptospirosis.

\section{RESUMO}

\section{Acometimento pancreático em casos fatais de leptospirose humana: aspectos clínicos e histopatológicos}

Hiperamilasemia tem sido documentada em mais de $65 \%$ dos pacientes com leptospirose severa, e o diagnóstico de pancreatite aguda torna-se difícil pelo fato de que a insuficiência renal pode aumentar os níveis séricos de amilase. Assim, foram analisadas, retrospectivamente, as características clínicas e histopatológicas do acometimento pancreático em 13 casos fatais de leptospirose humana. Os sinais e sintomas mais comuns foram febre, calafrios, vômitos, mialgia, desidratação, dor abdominal e diarréia. Trombocitopenia foi encontrada em 11 pacientes. Elevação dos níveis de AST e ALT foi observada em nove casos. Hiperamilasemia foi detectada em todos os pacientes em que foi dosada, com valores acima de $180 \mathrm{UI} / \mathrm{L}$ (três casos). Todos os pacientes desenvolveram insuficiência renal aguda e cinco necessitaram de tratamento dialítico. A principal causa de morte foi insuficiência respiratória devido à hemorragia pulmonar. Fragmentos do pâncreas foram obtidos para estudo histológico, e necrose gordurosa foi o critério utilizado para classificar pancreatite. Os achados histológicos foram edema pancreático, infiltrado inflamatório discreto de linfócitos, hemorragia, congestão, necrose gordurosa e calcificação. Deve-se suspeitar de acometimento pancreático em todo paciente com a forma grave de leptospirose que desenvolve dor abdominal.

\section{ACKNOWLEDGMENTS}

We wish to thank our colleagues, residents and nurses from Walter Cantídio University Hospital, Faculty of Medicine, Federal University of Ceará, São José Hospital of Infectious Diseases and General Hospital of Fortaleza (HGF) for the assistance provided to the patients. We also thank the contribution from the Department of Pathology, Faculty of Medicine, Federal University of Ceará, for the pathology support.

\section{REFERENCES}

1. ALLAM, B.F. \& IMRIE, C.W. - Serum ionized calcium in acute pancreatitis. Brit. J. Surg., 64: 665-668, 1977

2. AMBALOV, I.M.; KUSNETSOY, V.P. \& ZHUKOVA, K.I. - Spontaneous rupture of the spleen in a patient with leptospirosis. Klin. Med., 69: 91, 1991

3. AREAN, V.M. - The pathologic anatomy and pathogenesis of fatal human leptospirosis (Weil's disease). Amer. J. Path., 40: 343-414, 1962. 

features. Rev. Inst. Med. trop. S. Paulo, 45(6):307-313, 2003.

4. BECKINGHAM, I.J. \& BORNMAN, P.C. - ABC of diseases of liver, pancreas, and biliary system. Acute pancreatitis. Brit. med. J., 322: 595-598, 2001.

5. BELL, M.J.; TERNBERG, J.L. \& FEIGIN, R.D. - Surgical complications of leptospirosis in children. J. pediat. Surg., 13: 325-330, 1978.

6. CASELlA, G. \& SCATENA, L.F. - Mild pancreatitis in leptospirosis infection. Amer. J. Gastroent., 95: 1843-1844, 2000.

7. CHASE, C.W.; BARKER, D.E.; RUSSELL, W.L. \& BURNS, R.P. - Serum amylase and lipase in the evaluation of acute abdominal pain. Amer. Surg., 62: 1028-1033, 1996.

8. COMPANY, L.; SAEZ, J.; MARTINEZ, J. et al. - Factors predicting mortality in severe acute pancreatitis. Pancreatology, 3: 144-148, 2003.

9. CRAWFORD, J.M. \& COTRAN, R.S. - Pâncreas. In: COTRAN, R.S.; KUMAR, V.; ROBBINS, S.L. \& SCHOEN, F.J., ed. Robbins Patologia estrutural e funcional. 5. ed. Rio de Janeiro, Guanabara-Koogan, 1996. p. 806-833.

10. DAHER, E.; ZANETTA, D.M.; CAVALCANTE, M.B. \& ABDULKADER, R.C. - Risk factors for death and changing patterns in leptospirosis acute renal failure. Amer. J. trop. Med. Hyg., 61: 630-634, 1999.

11. DAHER, E.F. \& NOGUEIRA, C.B. - Evaluation of penicillin therapy in patients with leptospirosis and acute renal failure. Rev. Inst. Med. trop. S. Paulo, 42: 327-332, 2000

12. DAHER, E.F.; OLIVEIRA NETO, F.H. \& RAMIREZ, S.M.P. - Evaluation of hemostasis disorders and anticardiolipin antibody in patients with severe leptospirosis. Rev. Inst. Med. trop. S. Paulo, 44: 85-90, 2002.

13. DINH-ZARR, T.; DIGUISEPPI, C.; HEITMAN, E. \& ROBERTS, I. - Interventions for preventing injuries in problem drinkers (Cochrane Review). In: The Cochrane Library, Issue 1. Oxford, Update Software, 2003.

14. DUPONT, H.; DUPONT-PERDRIZET, D.; PERIE, J.L. et al. - Leptospirosis: prognostic factors associated with mortality. Clin. infect. Dis., 25: 720-724, 1997.

15. EDWARDS, C.N.; NICHOLSON, G.D.; HASSELL, T.A.; EVERARD, C.O.R. \& CALLENDER, J. - Leptospirosis in Barbados. W. Indian Med. J., 39: 27- 34, 1990.

16. EDWARDS, C.N. \& EVARARD, C.O.R. - Hyperamylasemia and pancreatitis in leptospirosis. Amer. J. Gastroent., 86: 1665-1668, 1991.

17. GREENBERGER, N.J. \& TOSKES, P.P. - Pancreatite aguda e crônica. In: BRAUNWALD, E.; FAUCI, A.S.; KASPER, D.L. et al., ed. Harrison Medicina interna. 15. ed. Rio de Janeiro, McGraw Hill, 2002. p. 1899-1911.

18. KO, A.I.; GALVÃO REIS, M.; RIBEIRO DOURADO, C.M.; JOHNSON Jr., W.D. \& RILEY, L.W. - Urban epidemic of severe leptospirosis in Brazil. Salvador Leptospirosis Study Group. Lancet, 354: 820-825, 1999.

19. LANCASHIRE, R.J.; CHENG, K. \& LANGMAN, M.J. - Discrepancies between population-based data and adverse reaction reports in assessing drugs as causes of acute pancreatitis. Aliment. Pharmacol. Ther., 17: 887-893, 2003.

20. LEVETT, P.N. - Leptospirosis. Clin. Microbiol. Rev., 14: 296-326, 2001.

21. LEVITT, M.D.; RAPOPORT, M. \& COOPERBAND, S.R. - The renal clearance of amylase in renal insufficiency, acute pancreatitis, and macroamylasemia. Ann. intern. Med., 71: 919-925, 1969.
22. LOMAR, A.V.; VERONESI, R.; BRITO, T. \& DIAMENT, D. - Leptospiroses. In: VERONESI, R. \& FOCACCIA, R., ed. Tratado de Infectologia. 2. ed. São Paulo, Atheneu, 2002. p. 1007-1023.

23. MANA, D.; KARANTZIAS, J.; BAGILET, D. \& RÍOS, R. - Leptospiroses e hiperamilasemia. Med. intens., 19: 16-18, 2000.

24. MARTINELLI, R.; LUNA, M.A. \& ROCHA, H. - Is rhabdomyolysis an additional factor in pathogenesis of acute renal failure in leptospirosis? Rev. Inst. Med. trop. S. Paulo, 36: 111-114, 1994.

25. McKAY, C.J. \& BUTER, A. - Natural history of organ failure in acute pancreatitis. Pancreatology, 3: 111-114, 2003.

26. MONNO, S. \& MIZUSHIMA, Y. - Leptospirosis with acute acalculous cholecystitis and pancreatitis. J. clin. Gastroent., 16: 52-54, 1993.

27. NANKIVELL, B.J. \& GILLIES, A.H. - Acute pancreatitis and rhabdomyolysis: a new association. Aust. N. Z. J. Med., 21: 414-417, 1991.

28. O'BRIEN, M.M.; VINCENT, J.M.; PERSON, D.A. \& COOK, B.A. - Leptospirosis and pancreatitis: a report of ten cases. Pediat. infect. Dis. J., 17: 436-438, 1998.

29. PANDIT, S. \& GREENE, C. - Leptospirosis: a rare cause of multiorgan failure. Hosp. Phycn., 74-77, 1999.

30. PLANK, R. \& DEAN, D. - Overview of the epidemiology, microbiology, and pathogenesis of Leptospira spp. in humans. Microbes Infect., 2: 1265-1276, 2000.

31. SCHECHTER, M. \& MARANGONI, D.V. - Doenças infecciosas: conduta diagnóstica e terapêutica. 2. ed. Rio de Janeiro, Guanabara Koogan, 1998.

32. SEGURO, A.C.; LOMAR, A.V. \& ROCHA, A.S. - Acute renal failure of leptospirosis: nonoliguric and hypokalemic forms. Nephron, 55: 146-151, 1990.

33. STOLZE, E.; SCHAAD, J.D.G. \& BOOL, P.H. - Weil's Disease associated with pancreatic necrosis. Report on a case. Trop. geogr. Med., 11: 93-95, 1959.

34. SUN, B.; LI, H.L., GAO, Y.; XU, J. \& JIANG, H.C. - Factors predisposing to severe acute pancreatitis: evaluation and prevention. Wld. J. Gastroent., 9: 1102-1105, 2003.

35. SURA, M.E.; HEINRICH, K.A. \& SUSENO, M. - Metronidazole-associated pancreatitis Ann. Pharmacother., 34: 1152-1155, 2000.

36. VANHOLDER, R.; SEVER, M.S.; EREK, E. \& LAMEIRE, N. - Rhabdomyolysis. J. Amer. Soc. Nephrol., 11: 1553-1561, 2000.

37. VINCENT, J.M.; O'BRIEN, M.M.; PERSON, D.A. \& COOK, B.A. - Leptospirosis and pancreatitis. Pediat. infect. Dis. J., 18: 400, 1999.

38. WATT, G.; PADRE, L.P.; TUAZON, M.L. et al. - Placebo-controlled trial of intravenous penicillin for severe and late leptospirosis. Lancet, 1: 433-435, 1988.

39. WILMINK, T. \& FRICK, T.W. - Drug-induced pancreatitis. Drug. Saf., 14: 406-423, 1996.

40. WILSON, P.G.; MANJI, M. \& NEOPTOLEMOS, J.P. - Acute pancreatitis as a model of sepsis. J. Antimicrob. Chemother., 41 (suppl. A): 51-63, 1998.

Received: 26 August 2003

Accepted: 3 November 2003.

\section{This article has received corrections in agreement with the ERRATUM published in Volume 46 Number 1.}

